\title{
Chemical Composition and Fertilizer Response of Two Range Plants in Relation to Grass Tetany ${ }^{1}$
}

\author{
J. AZEVEDO ${ }^{2}$ AND V. V. RENDIG 3 \\ President's Undergraduate Fellow and Professor of Soils and Plant \\ Nutrition, Department of Soils and Plant Nutrition, \\ University of California, Davis.
}

Highlight

The chemical response of two species of annual range plants, soft chess and broad-leaf filaree, to nitrogen and potassium fertilization was studied in a field plot trial in Amador County, California. Heavy losses of cows due to grass tetany have been reported from that vicinity in recent years.

The $\mathbf{K} /(\mathbf{C a}+\mathbf{M g})$ ratio in soft chess was significantly higher than that in broad-leaf filaree, and fertilization with $N$ and $K$ increased the ratio in both species. Fertilization increased the concentration of $\mathrm{K}$ in broad-leaf filaree, but had little effect on the concentrations of $\mathrm{Ca}$ and $\mathrm{Mg}$. In contrast, fertilization decreased the $\mathrm{Ca}$ and $\mathrm{Mg}$ percentages in soft chess but did not change the $\mathrm{K}$ concentration.

The presence of alkaloids in soft chess was detected by a "spot-test" technique.

There appears to be a lack of information regarding the relationship of the chemical composition of California range forage to the occurrence of grass tetany. Much of the information dealing with the forage aspects of this disorder was developed in areas where animals feed on more intensively managed pastures. As indicated in the review by Grunes, Stout and Brownell (1970) numerous studies in many areas of the world have been directed towards discovering the causes of grass tetany since Sjollema (1930) reported that the syndrome (called Kopziekte) was associated with a low serum magnesium level. 'This feature also appears to be characteristic of the disorder as observed on California ranges (Hjerpe, 1965).

Because a number of plant and animal factors are involved (Stevenson and Wilson, 1963) it has not been possible to define simply the occurrence of hypomagnesemic tetany in terms of the level of magnesium in feed eaten by the animals.

\footnotetext{
${ }^{1}$ Received January 29, $197 \mathrm{I}$.

${ }^{2}$ Present title is Laboratory Assistant. ${ }^{3}$ We would like to thank Mr. Robert Plaister, Amador County Farm Advisor, for his valuable assistance in the field studies.
}

Kemp and 't Hart (1957) reported a significant correlation between the incidence of grass tetany and the $\mathrm{K} /(\mathrm{Ca}+\mathrm{Mg})$ ratio in the forage. Other workers obtained similar results in their studies of tetany with beef breeding cows in New Zealand (Metson et al., 1966) and with dairy cows in Scotland (Butler et al., 1963).

Fertilization of forage with nitrogen and potassium has been found to increase the $\mathrm{K} /(\mathrm{Ca}+\mathrm{Mg})$ ratio in the plants (Kemp and ' $t$ Hart, 1957). Also this was shown to increase the incidence and severity of grass tetany (Kemp and 't Hart, 1957; Bartlett et al., 1954), and to decrease the serum magnesium in grazing animals ('t Hart, 1960; Kemp, 1958, 1960; Kemp et al., 1960). Kemp et al. (1961) also reported that forage fertilized with nitrogen and potassium had less magnesium available to the animal.

Some other nervous disorders characterized by tetanic convulsions have been tentatively traced to high amounts of alkaloids in the forage. Aasen et al. (1969) reported from studies in Australia the occurrence of ryegrass staggers in sheep and cattle grazing pastures consisting solely of ryegrass seedlings and newshoot growth. The perloline and holostachine alkaloids were found to be more abundant at this early stage of growth, and the level in the plant seemed to be dependent on climatic conditions. Culvenor, Dal Bon, and Smith (1964), in reporting the presence of tryptamine alkaloids in Hardinggrass (Phalaris tuberosa), suggested that these compounds may be responsible, in part, for the Phalaris staggers disorder in Australia.

Metson et al. (1966) perceptively summed up the voluminous work related to tetany as follows: "The extensive and often apparently contradictory literature on grass tetany and related disorders, offers ample scope for the construction of plausible hypotheses to account for any given set of observations, and whatever hard facts happen to be available." Even though grass tetany has been a problem for more than 100 years, the complex of factors contributing to this disorder is still uncertain. A comprehensive reexamination of the old hypotheses and testing of new, reasonable ones should be initiated to arrive at a workable solution to the problem.

The purpose of the present study was to determine the effects on plant chemical composition from additions of $\mathrm{N}$ - and $\mathrm{K}$-containing fertilizer to a soil in the Sierra foothills in Amador County.

\section{Experimental}

A virgin annual grassland area in western Amador County, California, was selected for the trial. Ranchers in the vicinity suffered heavy animal losses due to grass tetany in the winter of 1963-1964 (Hjerpe, 1965).

Three replicate pairs of plots, each $10 \mathrm{ft}^{2}$, were located randomly in a 40-acre field. One plot in each pair served as a control. The other was fertilized in early January with an equivalent of 300 pounds ammonium sulfate/acre and 400 pounds potassium sulfate/acre. To insure a uniform application, the fertilizers were dissolved in water and then sprinkled on the plots. The treatment was repeated halfway through the 3-month trial. 
Animal exclosures were placed around each plot, and these, in turn, were surrounded by barbedwire fencing to give further protection.

The forage was sampled initially in early January at the time of the first fertilizer treatment. Since the several kinds of grasses could not be identified in their early vegetative stages, a composite grass sample was used for analysis. An investigation of botanical composition at a later stage of development revealed a predominance of soft chess (Bromus mollis). Two other grass species, ripgut (Bromus diandrus) and slender wild oat (Avena barbata), were present in very small quantities. One species of forb, broad-leaf filaree (Erodium botrys), was present in sufficient quantities for sampling in five of the six plots, and later in the season it became sufficiently abundant to sample in the sixth plot. More frequent sampling was not feasible because of insufficient growth on the control plots.

Plant samples were dried for 2 days at $70 \mathrm{C}$, and then were ground in a Wiley Mill to pass a 40-mesh screen. Cations were solubilized by digesting the ground material with a nitric-ternary acid mixture, as suggested by Johnson and Ulrich (1959). Calcium, $\mathrm{Mg}$, and $\mathrm{K}$ were determined by atomic absorption spectrophotometry, using Cs and $\mathrm{La}$ in $1 \mathrm{~N}$ nitric acid to suppress external interference (Brownell, J. R., 1969).

The replicate treatments were composited to provide sufficient sample for determination of alkaloids. Their presence was detected by a "spot-test" technique (Raffauf, 1962). Color was developed using the modified Dragendorff reagent of Thies and Reuther, as described by Block, Durrum, and Zweig (1958).

Soil samples taken from the top 6 inches of each plot at the end of the trial were air-dried and sieved through a 2-mm mesh screen. Exchangeable cations were extracted by leaching the soil with $1 \mathrm{~N}$ am-

Table 1. Composition $(\mathrm{meq} / \mathrm{kg})$ of fertilized and unfertilized soft chess and broad-leaf filaree at three sampling dates. Fertilizer applied on January 6 and February 22. Mean values of three replicates.

\begin{tabular}{|c|c|c|c|c|c|c|}
\hline \multirow{2}{*}{$\begin{array}{l}\text { Species and } \\
\text { sampling date }\end{array}$} & \multicolumn{2}{|c|}{$\mathrm{Ca}$} & \multicolumn{2}{|c|}{$\mathrm{Mg}$} & \multicolumn{2}{|c|}{ K } \\
\hline & Unfert. & Fert. & Unfert. & Fert. & Unfert. & Fert. \\
\hline \multicolumn{7}{|l|}{ Soft chess } \\
\hline January 6 & 266 & 246 & 144 & 143 & 747 & 700 \\
\hline January 31 & 220 & 183 & 142 & $107^{a}$ & 801 & 797 \\
\hline March 7 & 253 & $163^{b}$ & 142 & $102^{a}$ & 814 & 862 \\
\hline \multicolumn{7}{|l|}{ Broad-leaf filaree } \\
\hline January $6^{*}$ & 426 & 484 & 154 & 162 & 519 & 587 \\
\hline January $31^{*}$ & 472 & 414 & 162 & 121 & 618 & 774 \\
\hline March 7 & 602 & 519 & 178 & 156 & 537 & $755^{\mathrm{a}}$ \\
\hline
\end{tabular}

"Significantly different from unfertilized at the $95 \%$ confidence level.

b Significantly different from unfertilized at the $99 \%$ confidence level.

* Means of two replicates only (see text).

monium acetate solution, $\mathrm{pH} 7$, as outlined by Chapman and Pratt (1961). Water-soluble cations were extracted from the saturation paste. Calcium, $\mathrm{Mg}$, and $\mathrm{K}$ were determined in $1 \mathrm{~N}$ nitric acid solutions by atomic absorption spectrophotometry.

\section{Results and Discussion}

The two species studied differed significantly in their reaction to the fertilization treatment (Table 1). In broad-leaf filaree, the $\mathrm{K}$ percentage was increased, but the $\mathrm{Ca}$ and $\mathrm{Mg}$ concentrations remained unchanged. In contrast, the levels of $\mathrm{Ca}$ and $\mathrm{Mg}$ in soft chess were depressed by fertilization, but percent $\mathrm{K}$ remained unchanged. The increase in percentage of $\mathrm{K}$ in broadleaf filaree and decrcase of $\mathrm{Ca}$ in soft chess, for the January 31 sampling, was found to be statistically significant at the $90 \%$ confidence level.

The $\mathrm{K} /(\mathrm{Ca}+\mathrm{Mg})$ ratio in the plants was also calculated (Fig. 1). Kemp and 't Hart (1957), in discussing the significance of this ratio in relation to the occurrence of grass tetany have indicated that the disorder seems to occur far more frequently when the ratio is above 2.2. Butler et al. (1963) stated that this ratio has no physiological basis, but that it may indicate the presence of other tetany-producing factors and thus may be useful in predicting the occurrence of grass tetany.
In the present study, soft chess consistently had a significantly higher $\mathrm{K} /(\mathrm{Ca}+\mathrm{Mg})$ ratio than did broad-leaf filaree. This is in agreement with a report by Thompson (1960) indicating that grasses have a higher ratio of monovalent to divalent cations than do broadleaved species. Fertilization with ammonium and potassium sulfates increased the $\mathrm{K} /(\mathrm{Ca}+\mathrm{Mg})$ ratio in both soft chess and broad-leaf filaree, and brought the ratio in soft chess well over the critical level of 2.2. Increases in the ratio as a result of fertilization have also been reported by Kemp and 't Hart (1957) working with a mixed forage. They, as well as others (Bartlett et al., 1954; Kemp, 1958), have also shown that nitrogen and potassium fertilization increases the incidence of grass tetany.

The growth habits of soft chess and broad-leaf filaree become significant in relation to grass tetany when we consider the differences in $\mathrm{K} /(\mathrm{Ca}+\mathrm{Mg})$ ratios between the two. Early in the growing season broad-leaf filaree is low and somewhat sheltered from the grazing animal by the tall, abundant soft chess. Later, however, the filaree, with the lower $\mathrm{K} /(\mathrm{Ca}+\mathrm{Mg})$ ratio, grows to some height and a significant amount can be ingested by the animal. Although this generalization ignores animal preferences, a change in feeding habits may contribute to observed decrease in 


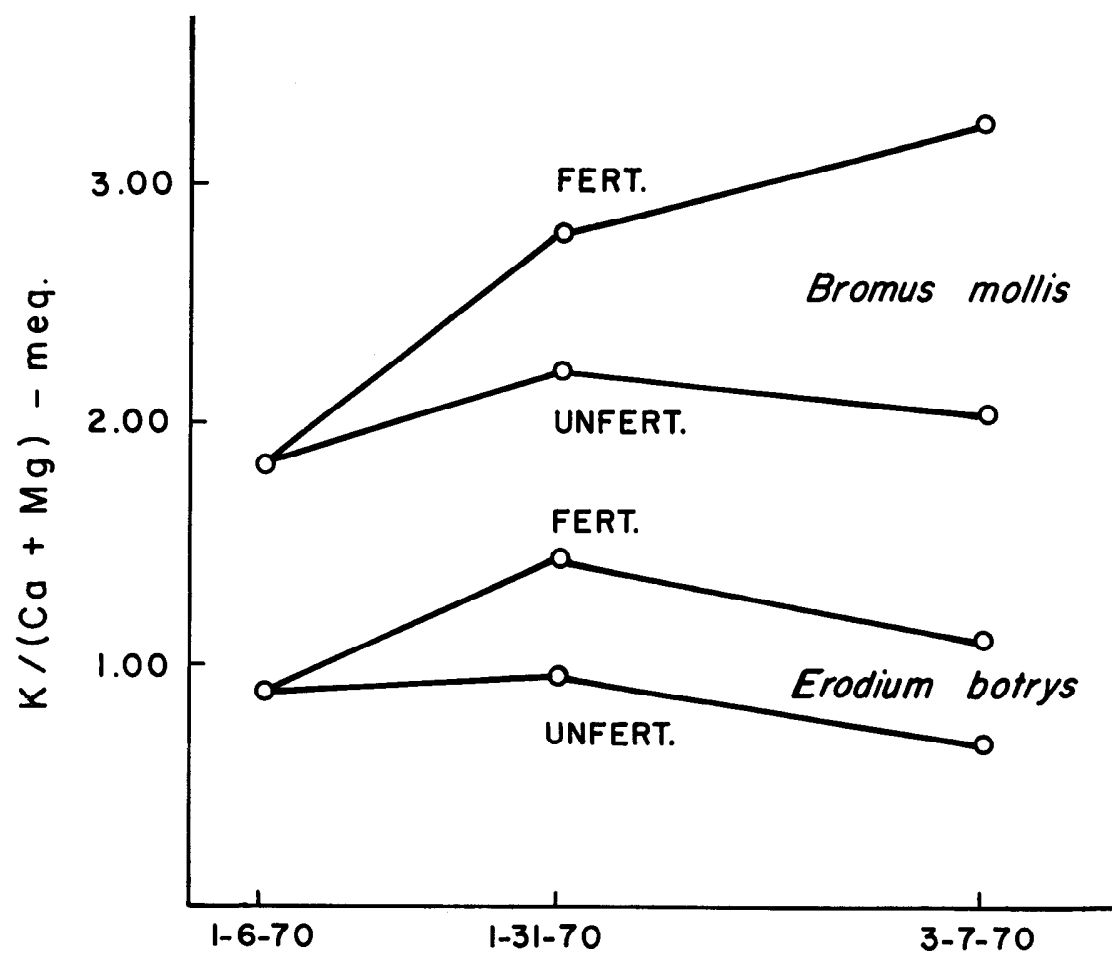

Fig. 1. The $\mathrm{K} /(\mathrm{Ca}+\mathrm{Mg})$ ratio of fertilized and unfertilized soft chess and broad-leaf filaree at three sampling dates.

deaths from grass tetany as the forage matures (Grunes et al., 1970).

The differences between the $\mathrm{K} /(\mathrm{Ca}+\mathrm{Mg})$ ratios in the two species should be considered in range management. Although reseeding of native pasture in the California foothills is usually not economically feasible, there is an obvious possibility of decreasing deaths from grass tetany by introducing species with naturally low $\mathrm{K} /(\mathrm{Ca}+\mathrm{Mg})$ ratios. Butler and Metson (1967) have suggested a similar "selection" process as a means for controlling grass tetany.

The soils in the trial area are moderately acidic and generally regarded as low in fertility (USDA,
1965). Fertilization appeared to increase the exchangeable $\mathrm{K}$ (Table 2). No other significant trends were observed.

Alkaloids were detected in all samples of soft chess. However, the method was not quantitative, and thus no actual values are reported. Relative values could not be satisfactorily measured because of interference from pigments in the plant juices.

The findings of this study illustrate the kind of complexities that can be encountered in attempting to relate intra- and inter-plant species differences to possible effects on fecd value. While soft chess might more likely be implicated as

Table 2. Composition (meq/kg) of soils collected on May 2. Mean values of three replicates.

\begin{tabular}{llllllll}
\hline \hline & \multicolumn{3}{c}{ Unfertilized } & & \multicolumn{3}{c}{ Fertilized } \\
\cline { 2 - 4 } \cline { 6 - 8 } & \multicolumn{1}{c}{$\mathrm{K}$} & $\mathrm{Ca}$ & $\mathrm{Mg}$ & & $\mathrm{K}$ & $\mathrm{Ca}$ & $\mathrm{Mg}$ \\
\hline Soluble $^{1}$ & $0.018^{2}$ & $0.028^{2}$ & $0.012^{2}$ & & $0.070^{\mathrm{a}}$ & 0.089 & 0.031 \\
Exchangeable & 0.233 & 3.887 & 1.213 & & 0.617 & 3.800 & 0.867 \\
\hline
\end{tabular}

${ }_{1}$ Determined on the saturation extract.

2 Mean of two replicates only.

a Significantly different from unfertilized at the $90 \%$ confidence level

a contributor to tetany problems because of its $\mathrm{K} /(\mathrm{Ca}+\mathrm{Mg})$ ratio, account should also be taken of possible effects due to the alkaloids which it likewise contains. Possibly a toxic effect of the alkaloids could, as additive or interacting factors, precipitate the disorder under certain conditions. The concentration of alkaloids in plants varies with environmental conditions and age of plant (Sokolov, 1959). Very little is known about the pharmacological effects of alkaloids in relation to animal constitution and individuality. Further studies into these areas are certainly warranted.

\section{Literature Cited}

Aasen, A. J., C. C. J. Gulvenor, E. P. Finnie, A. W. Kellock, and L. W. SMITH. 1969. Alkaloids as a possible cause of ryegrass staggers in grazing livestock. Aust. J. Agr. Res. 20: 71-86.

Bartlett, S., B. B. Brown, A. S. Foot, S. J. Rowland, R. Allcroft, and W. H. PArr. 1954. The influence of fertilizer treatment of grassland on the incidence of hypomagnesaemia in milking cows. Brit. Vet. J. 110: 3-19.

Block, R. J., E. L. Durrum, and G. ZwEIG. 1958. A manual of paper chromatography and paper electrophoresis. Second Edition. Academic Press, New York. $710 \mathrm{p}$.

Brownell, J. R. 1970. Geobiological influences on natural redistributions of rubidium relative to potassium in plants and soils. Ph.D. Thesis, University of California, Davis. Dissertation Abs. 31(6)B:3108.

Butler, G. W., ANd A. J. Metson. 1967. Hypomagnesaemic tetany in relation to New Zealand and dairyfarming. Dairyfarming Ann. p. 142-153.

BUtLer, E. J., AND VETERINARY INVESTIGATION AND AGRICULTURAL ADVISORY OFFICERS OF THE EAST AND WEST OF Scotland Agricultural Colleges. 1963. The mineral element content of spring pasture in relation to the occurrence of grass tetany and hypomagnesaemia in dairy cows. J. Agr. Sci. 60:329-340.

Chapman, H. D., and P. F. Pratt. 1961. Methods of analysis for soils, plants, and waters. Univ. of Calif. Div. of Agr. Sci. $390 \mathrm{p}$.

Culvenor, C. C. J., R. Dal Bon, and L. W. Sмith. 1964. The occur- 
rence of indole alkylamine alkaloids in Phalaris tuberosa and P. arundinacea L. Aust. J. Chem. 17:1301-1304. Grunes, D. W., P. R. Stout, and J. R. BRownELl. 1970. Grass tetany of ruminants. Advances in Agr. 22:331374.

HART, M. L. 'T. 1960. The influence of meterological conditions and fertilizer treatment on pasture in relation to hypomagnesaemia. British Veterinary Association Conference on Hypomagnesaemia. The Victoria Hall, Southhampton Row, London. 88-95.

HJERPE, C. A. 1965. Grass tetany in California cattle. J. Amer. Vet. Med. Assoc. 144:1406.

Johnson, C. M., AND A. Ulrich. 1959. Analytical methods for use in plant analysis. Calif. Agr. Exp. Sta. Bull. 766:25-78.

KEMP, A. 1958. Influence of fertilizer treatment of grassland on the incidence of hypomagnesaemic and hypomagnesaemic tetany (grass tetany) in milking cows. Neth. J. Agr. Sci. 6:281-297.
Kemp, A. 1960. Hypomagnesaemia in milking cows: the response of serum magnesium to alterations in hcrbagc composition resulting from potash and nitrogen dressings on pasture. Neth. J. Agr. Sci. 8:281-304.

Kemp, A., W. B. DeiJs, O. J. Hemkes, AND A. J. H. van Es. 1960. Intake and utilization of magnesium from herbage by lactating cows. British Veterinary Association Conference on Hypomagnesaemia. The Victorian Hall, Southhampton Row, London. pp. 23-32.

Kemp, A., W. B. Deijs, O. J. Hemkes, AND A. J. H. van Es. 1961. Hypomagnesaemia in milking cows: intake and utilization of magnesium from herbage by lactating cows. Neth. J. Agr. Sci. 9:134-149.

KeMP, A., AND M. L. 'T HART. 1957. Grass tetany in grazing milk cows. Neth. J. Agr. Sci. 5:4-17.

Metson, A. J., W. M. H. Saunders, T. W. Collie, and V. W. Graham. 1966. Chemical composition of pastures in relation to grass tetany in beef breeding cows. N. Z. J. Agr. Res. 9:410-436.

RafFauf, R. F. 1962. A simple field test for alkaloid-containing plants. Econ. Bot. 16:171-172.

SJollema, B. 1930. On the nature and therapy of grass staggers. (Trans., Abs.). Vet. Rec. 10:425-431, 450454.

SokoLov, V. S. 1959. The influence of certain environmental factors on the formation and accumulation of alkaloids in plants. Soc. Exp. Biol. Symp. XIII:230-257.

Stevenson, D. E., ANd A. A. Wilson. 1963. Metabolic disorders of domestic animals. F. A. Davis, Philadelphia. $198 \mathrm{p}$.

Thompson, A. 1960. Soil-plant-animal relationships and hypomagnesaemia. British Veterinary Association Conference on Hypomagnesaemia. The Victorian Hall, Southhampton Row, London. 75-83.

U. S. Department of Agriculture. 1965. Soil Survey, Amador County, Calif. Series 1961, No. 26. 167 p. 